\title{
Degradation of Commons Property Resources and its Impact on Livelihoods of Dependent Rural Community: A Case Study of Dindigul District, Tamil Nadu
}

\author{
Manu P. Pathak ${ }^{1}$ and P. Murugesan ${ }^{2}$ \\ ${ }^{1}$ Ph.D. Research Scholar, ${ }^{2}$ Assistant Professor, \\ Centre for Rural Development, Annamalai University, Chidambaram, Tamil Nadu, India \\ E-Mail: mpp16108@gmail.com, murugesancrd@gmail.com
}

\begin{abstract}
Throughout the world today, various common property resources systems are coming under increased pressure, particularly in the tropics and subtropics. Rapid rates of population growth, technological change, increases in the size of markets, and cultural changes, as well as uneven growth and persistent poverty, have often resulted in increased levels of utilization of various natural-resource-based systems. Forests are being cleared rapidly; groundwater is being pumped to the surface at an often alarmingly high rate; fish and wildlife populations are declining in the face of loss of habitat and high levels of harvesting; range and pasture lands are being overgrazed; and other example abound. Because the exploitation of these resource systems represents an important component in the livelihoods of people throughout Africa, Asia, and Latin America, their degradation cannot be ignored (David H. Feeny). The present study is conducted in Dindigul District in Tamilnadu consisted of 14 blocks. This study was carried out in 5 blocks namely Oddanchatram, Reddiyarchatrm, Dindigul, Sanarpatti and Vadamadurai. These blocks were identified based on the high level of CPR present over there. From each of the above mentioned identified block 5 village panchayats have been selected. The main objectives of the present study were to examine the dependency level of Common Property Resources(CPR) among the respondents and also to study the determinants of degradation of Common Property Resources (CPR) in the study area.
\end{abstract}

Keywords: Common Property Resources, Degradation, Population Growth, Livelihoods, Poverty

\section{I.INTRODUCTION}

The world today due to Rapid rate of population growth, massive technological change, increases in the size of markets, as well as uneven growth and persistent poverty, have often resulted in increased levels of utilization of various natural-resource-based systems resulting in decline of common property resources, such as degradation of pasture land, fishing ground, forest resources where community have access right. Exploitation of these resource systems represents an important component in the livelihoods of people throughout Africa, Asia, and Latin America. This study focuses on how degradation of common property (Land, water and forest) resources undermines sustainable rural livelihoods. Throughout the world today, various common property resources systems are coming under increased pressure, particularly in the tropics and subtropics. Rapid rates of population growth, technological change, increases in the size of markets, and cultural changes, as well as uneven growth and persistent poverty, have often resulted in increased levels of utilization of various natural-resource-based systems. Forests are being cleared rapidly; groundwater is being pumped to the surface at an often alarmingly high rate; fish and wildlife populations are declining in the face of loss of habitat and high levels of harvesting; range and pasture lands are being overgrazed; and other example abound. Because the exploitation of these resource systems represents an important component in the livelihoods of people throughout Africa, Asia, and Latin America, their degradation cannot be ignored. (David H. Feeny).

\section{OBJECTIVES OF THE STUDY}

1. To examine the dependency level of Common Property Resources(CPR) among the respondents

2. To study the determinants of degradation of Common Property Resources (CPR) in the study area.

\section{III.REVIEW OF LITERATURE}

Kannan\& Mari (2015) analysed that the CPR will be exhausted when extraction occurs at an unsustainable rate. Moreover, over extraction by one person increases the extraction costs of the other (Andrew B.Whitford, 2002). The consequent lack of resources for maintenance of CPRs and absence of provisions against their over extraction have initiated the process of depletion of CPRs (Raveendaran, 2003). Political instability, rapid population growth, management practices at the local level and social norms of behaviour are the direct cause of trigger resource depletion and environmental ruin (ParthaDasgupta, 2005). The immense use of CPRs has declined over the few decades may be the reason for introduction of new economic policy in general and globalization of commons in particular. The rural households formed the major beneficiaries of CPR. It looks obvious, from the fact that higher

Ratul Mahanta and Daisy Das (2012) studied the linkage between common property resources and migration in 
Assam. The hypothesis of the study to be tested is - a decline of common property resources associated with environmental degradation pushes rural people to migrate to urban areas. CPRs have been steadily declining in quantity and quality over the years (Chopra and Gulati 1998). This declining CPR extent and quality is important both for sustainability of CPR dependent livelihoods and the natural resources themselves (Chopra and Dasgupta 2002). According to the agricultural statistics of India, total CPR lands in the 16 states of India were 70.042 million hectares in 1990-911. Of this, 44.983 million hectares or about 64.23 percent was non-forest land. This estimate didn't include north-eastern states of India due to lack of reliable land record statistics. On the basis of available estimates, it can be concluded that had these states been included, the total CPR would have increased to 74.573 million hectares. Further, CPR area varies from25 to 52 percent of geographical area in these states (Kadekodi 1997).

Shiva LalBhushal (2009) Studied the causes and process of depletion of CPRs he stated the causes of CPRS decline are the human factors like socio-economic, legal, political and technical as well as environmental factors (natural factors). So the causes and process of CPRs decline in study area are summarized in the figure. The main causes of CPR decline are, summarized in main headings:

1. Increasing pressure on CPRs (due to population growth, poverty and marketing of CPRs. etc)

2. Lack of participatory and inclusive management, ignoring tradition always of protecting CPRs without replacing better ways, lack of sense of ownership, disregard of non-money values of CPRs and effect of structural change etc.

3. Shrinkage of CPRs (due to illegal accessing of local leader or others, distribution of CPRs for the welfare purpose, sale or privatization of CPRs by government of local community and side effect of other development activities etc) and

4. Natural disaster and lose of ecological or other environmental balance. The tectonic instability as well as the relatively young age of mountains lends themselves to high natural erosion. We can further summarizes these factors in two headings as (i) Decline in quality of CPRs and (ii)Decline in quantity of CPRS both by human and non-human factors.

\section{METHODOLOGY}

The Dindigul District in Tamil Nadu consisted of 14 blocks. This study was carried out in 5 blocks namely Oddanchatram, Reddiyarchatrm, Dindigul, Sanarpatti and Vadamadurai. These blocks were identified based on the high level of CPR present over there. From each of the above mentioned identified block 5 village panchayats have been selected. Further, 12 households have been identified from each village panchayat and total number of samples selected for the present study was 300 as mentioned below, by using Disproportionate Stratified Random Sampling method.
The data collection for this study was analysed by SPSS and MS Excel. The required data was collected from 300 rural households with the help of a pre-tested interview schedule prepared exclusively for this purpose. The data was consisting of items of information such as sociodemographic characteristics (age, religion, caste, marital status, education), Access to CPRs, Factors Affecting Degradation of CPRS, Impact of Loss of CPRs, The items of information collected through personal interview for their better livelihoods.

The survey data, after evaluation and coding, have been entered into spread sheets of Statistical Package of Social Science (SPSS). To understand the nature of the data, firstly, frequency tables were prepared, and subsequently the analysis and tabulation have been carried out using research techniques based on the requirement, further ChiSquare test and Binary Logistic Fittest Modeland Factor Analysis has been performed on the data. In very general terms, Factor Analysis (FA) can be seen as approaches to summarizing and uncovering any patterns in a set of multivariate data, essentially by reducing the complexity of the data. Principal component analysis is a multivariate technique for transforming a set of related (correlated) variables into a set of unrelated (uncorrelated) variables that account for decreasing proportions of the variation of the original observations. The rationale behind the method is an attempt to reduce the complexity of the data by decreasing the number of variables that need to be considered.

\section{RESULTS AND DISCUSSION}

Table I as shown above gives the sex distribution of sample respondents in the study areas. Sex distribution is an important factor in socio-economic status of the study area, as women also takes parts in the economic development of family which is directly related with access to basic facilities such as education, health, shelter etc. It is clearly evident from the above table that 61 percent of sample respondents are Male and rest 39 percent constitutes of women respondents. It is clear that the ratio of Men is higher in comparison to women is due to various reasons. In two women have comparatively higher in their participation in this survey. Above table clearly shows that women respondents constituted below 9 percent in almost all the five. Whereas among men respondents from Oddanchatram, Dindigul\&Sanarapatti Men's participation percentage is around 15 percentages and this indicates that respondents of these three are highly accessing the CPRs items which not only generating their livelihoods but also in day to day uses. Table I as shown above gives the occupation-wise distribution of sample respondents. Occupation of respondents is directly related with CPRs use and access. In general those people who are depending on Farming or doing Labour are more likely to dependent on Common Property Resources as CPRs constitute major income source and generated livelihoods in the forms of fuel wood, medicinal plant, use of common grazing land for cattle and 
pets, getting access to fallow or barren land. Self-employed, business and Govt. employee class of people in general do not depend on CPRs for their day to day livelihoods as their economy is largely not depends on it. However in rural villages still people use CPRs as it supports family economy. From the above table it is clearly revealed that among the surveyed respondents with 47 percentage farmers constituted highest, followed by labour in which coolie and mason workers are 35 percentages next is Govt. Employee with 11 percentage and self-employed and Business class constituted 7 percentages. Among block wise distribution of farmers from Oddanchatram constituted 23 percentage, Vadamadurai 20 percentage, Sanarapatti 23 percentage and Dindigul and Reddiyarchatram accounted for 16 and 18 percentages respectively. Labour constitutes at an average of 20 percentages from all surveyed self-employed, Business and Govt employed respondents constituted at an average of 8 percentage.

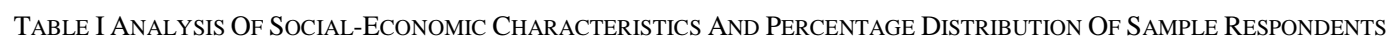

\begin{tabular}{|c|c|c|c|c|c|c|}
\hline $\begin{array}{c}\text { Background } \\
\text { characteristics }\end{array}$ & \multicolumn{5}{|c|}{ Name of the blocks (frequency in \%) } & \multirow[t]{2}{*}{$\begin{array}{c}\text { Total } \\
(\text { Frequency in \%) }\end{array}$} \\
\hline Variables & Oddanchatram & Reddiarchatram & Dindigul & Sanarapatti & Vadamadurai & \\
\hline \multicolumn{7}{|c|}{ Gender } \\
\hline Male & $34(18.5)$ & $33(17.9)$ & $35(19)$ & $42(22.8)$ & $40(21.7)$ & $184(61.33)$ \\
\hline Female & $26(22.4)$ & $27(23.3)$ & $25(21.6)$ & $18(15.5)$ & $20(17.2)$ & $116(38.66)$ \\
\hline \multicolumn{7}{|c|}{ Occupation } \\
\hline farmers & $32(22.5)$ & $23(16.2)$ & $26(18.3)$ & $33(23.2)$ & $28(19.7)$ & $142(47.33)$ \\
\hline Labour (Collie, Mason) & $22(20.8)$ & $27(25.5)$ & $24(22.6)$ & $13(12.3)$ & 20(18.9) & $106(35.33)$ \\
\hline $\begin{array}{l}\text { Self-employment, } \\
\text { Business) }\end{array}$ & $1(5)$ & $2(10)$ & $4(20)$ & $8(40)$ & $5(25)$ & $20(6.66)$ \\
\hline Govt. Employment & $5(15.6)$ & $8(25)$ & $6(18.8)$ & $6(18.8)$ & $7(21.9)$ & $32(10.66)$ \\
\hline \multicolumn{7}{|c|}{ Do you have cattle? } \\
\hline Yes & $57(26.3)$ & $58(26.7)$ & 41(18.9) & $27(12.4)$ & $34(15.7)$ & $217(72.33)$ \\
\hline No & $3(3.6)$ & $2(2.4)$ & $19(22.9)$ & $33(39.8)$ & $26(31.3)$ & $83(27.66)$ \\
\hline \multicolumn{7}{|c|}{ Reasons for collecting MFP } \\
\hline Personal Use & $14(13.3)$ & $29(27.6)$ & $21(20)$ & 19(18.1) & $22(21)$ & $105(35)$ \\
\hline For Selling Purpose & $15(22.7)$ & $12(18.2)$ & $16(24.2)$ & 13(19.7) & $10(15.2)$ & $66(22)$ \\
\hline Both & $31(24)$ & 19(14.7) & 23(17.8) & $28(21.7)$ & $28(21.7)$ & $129(43)$ \\
\hline \multicolumn{7}{|c|}{ Earning from MFP (per month) } \\
\hline Rs.1000-2000 & $34(18.1)$ & $41(21.8)$ & $37(19.7)$ & $40(21.3)$ & $36(19.1)$ & $188(62.66)$ \\
\hline Rs. 2001-4000 & $19(25)$ & $17(22.4)$ & $17(22.4)$ & $10(13.2)$ & $13(17.1)$ & $76(25.33)$ \\
\hline Rs.5000 and above & $7(19.4)$ & $2(5.6)$ & $6(16.7)$ & $10(27.8)$ & $11(30.6)$ & $36(12)$ \\
\hline
\end{tabular}

Source: Computed (Demographic\& Socio-Economic Characteristics N=300)

Table I shows distribution of surveyed respondents as per land holding. Availability of land is directly related with economic status of the individual. Land rights are often a vital element when rural households balance their capabilities and assets, and determine their resulting strategies to cope with their daily production and food security. However, rights to land are not just a source of economic production, but are also a basis of social relationships and cultural values, and a source of prestige and often power. The resulting social networks that are built up within a specific social and cultural group are a very important asset in ensuring sustainability of livelihoods of rural households.In all the civilization livestock was always considered as wealth for the family or community, cattle remained the determinant of social and economic status till now in many part of the world. Even in India still many farming community depends upon cattle for their day to day need. But this trend in slowly declining due to various factors namely modernization of agriculture which include introduction of heavy machinery for tilling, and harvesting crop and transportation. And also less availability of Common Grazing land also discouraged the farmers to keep the cattle as purchasing of fodder is not affordable for rural farmers. In the surveyed area 21 percentage of respondents said that they did not have cattle 79 percentages of families reported to have cattle. This trend is changing slowly due to various factors. Among the surveyed 79.4percent of sample families had cattle of different kinds and the rest did not have them. Of the five covered for the study, Dindigul block had less number (7.15 percent) of cattle population as reported by the sample respondents from the block concerned. Forests and village commons have been important sources of supplementary livelihoods and basic necessities for rural households in many parts of the world. 
"More than 1.6 billion people depend to varying degrees on forests for their livelihoods. About 60 million indigenous people are almost wholly dependent on forests. In developing countries, about 1.2 billion poor people rely on forest resources for their livelihood, and 80 percent of the people depend on non-wood forest products, such as fruits and herbs, for their primary health and nutritional needs".In South Asia the CPRs have provided fodder, small timber and various non-timber products. Firewood is still the single most important source of rural domestic energy in South Asia, and is still largely gathered, and not bought from outside. The above table clearly shows that 45.5 percent of sample households have collected CPRs for personal use and also for selling of the same. In the case of 32.1 percent of them it was reported that they collected for personal use only and 22.4 per cent stated sales as the reasons for collection of CPRs. The people were free to collect Minor Forest Product and they were dependent on Minor Forest Product for their livelihood and they felt that it was a legal right. But during the British period, tribal people were restricted to collect Minor Forest Product, because Britishers established the Forest Department in 1864 to check the deforestation and to have monopoly over the forest. Even though small, though the income from the Minor Forest Products does supplement the income from agriculture and wage labour such that the people put a premium on their dependence on the Minor Forest Products. They have some limitations on the produce they may collect from the forests. It is a man's job as well, not that women do not try their hands at its, they do, and some are habitual and good collectors of Minor Forest Product. Fruits and roots, dead wood, soapberry and other such Minor Forest Products are not difficult to collect but are becoming short of their supply because of increasing number of collectors and increasing restrictions on their collection, more so, with the declaration of certain areas of the forests as wild life sanctuaries and forest reserves for regeneration. The above table shows that majority (64.3 percent) of sample households have earned Rs.1000-2000 from Minor Forest Product per month and 25.5 percent of them reported that they obtained income from Minor Forest Product in the range of Rs.2001-4000 per month. In the case of 10.2 of sample households, it was reported that they could earn above Rs. 5000 per month from Minor Forest Product.

Table Ii Percentage Distribution Of SAmple Respondents For DeClining Of Cpr And Its Impact On RuRal Livelihoods

\begin{tabular}{|c|c|c|c|c|c|c|}
\hline Background characteristics & \multicolumn{5}{|c|}{ Name of the blocks (frequency in \%) } & \multirow{2}{*}{$\begin{array}{c}\text { Total } \\
\text { (Frequency in } \\
\%) \\
\end{array}$} \\
\hline Variables & Oddanchatram & Reddiarchatram & Dindigul & Sanarapatti & Vadamadurai & \\
\hline \multicolumn{7}{|c|}{ Had CPR decreased? } \\
\hline Yes & $47(19)$ & $50(20.2)$ & $45(18.1)$ & $53(21.4)$ & $53(21.4)$ & $248(82.66)$ \\
\hline No & 26.1 & $7(15.2)$ & $14(30.4)$ & $7(15.2)$ & $6(13)$ & $46(15.33)$ \\
\hline do not know & $1(16.7)$ & $3(50)$ & $1(16.7)$ & $0(0)$ & $1(16.7)$ & $6(2)$ \\
\hline \multicolumn{7}{|c|}{ Reasons for migration } \\
\hline Less CPR availability & 19.7 & $26(19.7)$ & $18(13.6)$ & $24(18.2)$ & $38(28.8)$ & $132(44)$ \\
\hline No sufficient work at the previous place & 27 & $30(27)$ & $25(22.5)$ & 13(11.7) & $13(11.7)$ & 111(37) \\
\hline No enough income for the work & $3(10.3)$ & $2(6.9)$ & $8(27.6)$ & $16(55.2)$ & $0(0)$ & $29(9.66)$ \\
\hline Relative migration & $1(3.6)$ & $2(7.1)$ & $9(32.1)$ & $7(25)$ & $9(32.1)$ & $28(9.33)$ \\
\hline \multicolumn{7}{|c|}{ CPR is degraded most in } \\
\hline Pasture land & $21(17.1)$ & $29(23.6)$ & $29(23.6)$ & $23(18.7)$ & $21(17.1)$ & $123(41)$ \\
\hline Water resources & $18(18.8)$ & $16(16.7)$ & $18(18.8)$ & $20(20.8)$ & $24(25)$ & $96(32)$ \\
\hline Forest resources & $18(25.7)$ & 13(18.6) & $10(14.3)$ & $14(20)$ & $15(21.4)$ & $70(23.33)$ \\
\hline All above & $3(27.3)$ & $2(18.2)$ & $3(27.3)$ & $3(27.3)$ & $0(0)$ & $11(3.66)$ \\
\hline \multicolumn{7}{|c|}{ Is there migration in village due to $\mathrm{CPR}$ loss } \\
\hline Yes & $36(20.5)$ & $31(17.6)$ & $37(21)$ & $40(22.7)$ & $32(18.2)$ & $176(58.66)$ \\
\hline No & $24(19.4)$ & $29(23.4)$ & $23(18.5)$ & $20(16.1)$ & $28(22.6)$ & $124(41.33)$ \\
\hline \multicolumn{7}{|c|}{ Other possible effects of loss of CPRs } \\
\hline Unemployment & $28(26.4)$ & 19(17.9) & 19(17.9) & 20(18.9) & 20(18.9) & $106(35.33)$ \\
\hline Changes in life style & $26(16.6)$ & $40(25.5)$ & $32(20.4)$ & $34(21.7)$ & $25(15.9)$ & $157(52.33)$ \\
\hline Climate change & $6(16.2)$ & $1(2.7)$ & $9(24.3)$ & $6(16.2)$ & $15(40.5)$ & $37(12.33)$ \\
\hline \multicolumn{7}{|c|}{ Does Loss of CPRs affect your life? } \\
\hline Yes & $32(16.5)$ & $39(20.1)$ & $46(23.7)$ & $37(19.1)$ & $40(20.6)$ & 194(64.66) \\
\hline No & $28(26.4)$ & $21(19.8)$ & $14(13.2)$ & $23(21.7)$ & $20(18.9)$ & $106(35.33)$ \\
\hline
\end{tabular}


The decrease of CPRs includes those resources which are commonly in use which includes common water resources such as village or community ponds, tanks, reservoirs etc and in land resources common grazing, threshing land etc. in addition to this common forest where community members collect minor forest products is very essential. These are the resources which determine socio-economic condition and helps in day to day livelihoods of the local population as their life is dependent on these resources. It is also very interesting to note that many young generation do not know their particular right about common resources and its important as source of livelihoods reason for which could be due to change in economic structure of society. However, the older generation still collect from their memory about previous use of CPRs and present limitation of it. From the surveyed villages 83 percent of respondents stated that they were well aware of decline of CPRs and whereas 15percent of them did not know that the CPRs have been declining. Another 2 percent of sample respondents stated that they did not know anything on the decline of CPRs in their villages.

The reasons for decrease of cattle are directly associated with availability of Common Property Resources in rural areas which mainly include Common grazing land and common water resources. Due to decline of common resources keeping cattle is becoming very difficult in present context. In present surveyed area out of 300 respondents, 61 percentages have said that due to nonavailability of grazing land they are not keeping the cattle and this trend is very common in all the five. Another 23.4 percentage of respondents have said that due to loss of CPRs and being part of nuclear family, it was very difficult to maintain the cattle and rest (15.5 percentages) of respondents said that due to less family income they were unable to keep the cattle. Above table reflects the response of respondents on the reasons for their migration from their villages to another village or town. As per the surveyed data it is found that 30 percent of respondents informed that their migration was directly related with CPR availability in other places. Non availability of work in the native villages was the reason for migration to potential places was cited by 29.9 percent of sample households. Due to migration of relatives was cited by 20 percent of respondents and lack of adequate income as the reason for migration was stated by another 20 percent of respondents. Similarly it was stated by 20 percent of sample respondents that they have migrated as their relatives also have already migrated.

Further, knowledge on the decline of forest is also very important for sustainable development of forests. In this regard, it is noted from the above table that 68.9 percent of sample household were aware of the phenomenon of forest decline in general and study areas in particular. The households that were unaware of decline of forest resources constituted 24.3 percent of sample households and 6.8 percent of them stated that they were unaware of forest resources decline.In addition, environmental degradation caused considerable hardships to fuel wood collectors in rural areas. In this context, it is worth probing the forces at work in discerning the access to all forms of CPRs across all sections of rural population. The above table clearly shows that majority of sample households (68.5 percent) reported that they had the knowledge of decline of CPRs in the study areas and 13.1 percent of them did have any awareness on the decline of CPRs. Further, 18.4 percent of them did not express any opinion on the decline. It is seen from the above table that 37.3 percent of sample households stated that the sources of common water resources have declined and decline of pasture lands and forest resources were cited by 33.3 percent and 26.2 percent of them respectively. And another 3.2 percent of them have reported that all the above mentioned CPRs have degraded. Obviously all the sample household were in agreement regarding the degradation of CPRs in the study pockets.Deterioration of common property resources increases the incidence of poverty level because poor people depend on forest resources. Earnings of rural people are mostly the combination of income from private property and common property resources. Reduction in common property resources reduces earnings of rural people leading them to migrate to nearby urban areas in search of livelihood. Thus, there is a link between common property resource degradation, poverty and migration. On the basis of these arguments, an attempt has been made to study the linkage between common property resource degradation and migration. It is found from the above table that the decline of CPRs caused seasonal migration in the case of 58 percent of sample households and 42 percent of them reported permanent migration from the native villages due to such decline.

The reduction in land area, poor maintenance and the decline in carrying capacity lead to reduced supplies of products for those who depend on common property resources. Seen in relation to earlier evidence of the rural poor's heavy dependence on these resources, their decline represents a definite step towards further pauperization of the poor. This is a classic case of the vicious circle of poverty and resource degradation reinforcing each other.Table II clearly shows that 52 per cent of sample households informed that there life style has changed as a result of loss of CPRs and 32 per cent of them stated that loss of CPRs caused unemployment problem. In the cause of 16 per cent of sample households, it was reported that climate has changed due to loss CPRs. The above table clearly indicates the views of sample households on the loss of CPRs and its effects on their livelihood in the study areas. It is noted from the above that majority of sample households (69 per cent) have reported that the loss of CPRs had it is effect on their livelihoods directly as also indirectly.

However, 31 percent of them didn't experience ill effect of loss of CPRs in their livelihoods.A number of welfare and development interventions have had severe negative side effects on CPRs. CPR land has been lost severely. Such declines in CPRs have also been noted that the poor households are losing access to CPRs. The extent and decline was between 26 per cent and 52 per cent are mainly 
due to the primary factors behind the degradation of CPRs as undeclared regressive state policies, encouraging privatization and neglect of CPRs. The nature of effect of loss of CPR as reported by the sample households is presented in table II . It is noted from the table that effect such as climate change ( 22 percent), pollution ( 25 percent) and water scarcity (10 per cent). Further, it was of the opinion of 28 percent of sample Households that loss of CPR in the study areas has altered their life style artificially and other 14 per cent of them reported that lack of Knowledge of management of CPRs and it is conservation were the reasons for loss of CPR and its consequences as reported above.

\section{CONCLUSION}

This has been an established fact that the entire process of development of rural economy is somehow linked to the availability of common and natural resources surrounding it. Besides incomparable and non-enumerable contribution to ecology, climate and environment, the common property resources (CPRs) can generate scope of income employment for the rural poor, and spillover benefits to agriculture, cottage industries and livestock economy. The study indicated that the sample households had the knowledge of decline of CPRs in the study areas. It is evident from the study that the sources of common water resources have declined and decline of pasture lands and forest resources were also reported by the respondents. Due to decline of CPRS, out-migration of local populace was reported .On the basis of these arguments, an attempt has been made to study the linkage between common property resource degradation and migration. It is found that the decline of CPRs caused seasonal migration in the case of 58 percent of sample households and 42 percent of them reported permanent migration from the native villages. This study also reported the negative effects such as climate change, pollution artificial life style on account of decline CPR. Further, it has shown that the local community had little control over CPR governance and people were lacking in knowledge of management and conservation of CPRs. These reasons have also contributed for decline of CPRs in the study areas.

The Common Property Resources (CPRs) have been contributing a lot to the village economies and local communities in general and the poor in particular survive on these resources to a large extent. The immediate consequence of increased pressure on such resources is their overexploitation and degradation. The decline in the number of products also suggests reduced biodiversity in common property resources. The findings of the present study have important implications: improving the quality of natural resources will have a lasting impact on reducing poverty. If dependence on resources did decrease with income--the conventional wisdom--then efforts to improve the village natural resource base would help the poorest of the poor immediately. However, as these households made their way out of poverty they would turn to sources of income other than those based on natural resources and would no longer benefit from efforts to improve their environment. Improvements to the natural resources would, on the other hand, have a lasting impact on poverty if both the poor and the rich are dependent on these resources. Even as household incomes improve, households will continue to draw on natural resources to earn a living. Furthermore, enabling the poor households with suitable policies would go a long way in ensuring their empowerment.

\section{REFERENCES}

[1] Agarwal, A. (2005). Explaining Success on the Commons: Community Forest Governance in the Indian Himalaya. World Development, 34(1), pp. 149-166.

[2] Arjunan, M., et al. (2005). The impact of resource collection by local communities on the dry forests of the Kalakad-Mundanthurai Tiger Reserve, India. Tropical Ecology, 46, 135-143.

[3] Bhim, A. (2001). Property Rights and Natural Resources: Impact of Common Property Institutions on Community-Based Resource Management, The University of York, Heslington, York, YO10 5DD, United Kingdom.

[4] Bogahawatt. (1986), Erosion of Common Property Resources: Evidence from Village in the Drezone Districts of Srilanka, Agricultural Administration, (23) pp.191-199.

[5] Dasgupta, Partha. (2005), Common Property Resources: Economic Analytics, Revised, March University of Cambridge.

[6] David R. Lee, et al. (2009). Background Paper for Chapter 2 of the International Fund for Agricultural Development's 2009 Rural Poverty Report, and was developed under contract with IFAD. Agricultural Development Economics Division, Food and Agricultural Organization of the United Nations, Rome, Italy.

[7] Jodha (1992). Common Property Resources: A Missing Dimension of Development Strategies, World Bank Discussion Papers, (169), 3639.

[8] Kannan\& Mari. (2015). Issues in the Utilization of Common Property Resources (CPRS): A Case Study of T.NaganiPanchayat in Ramanathapuram District, Tamil Nadu, Asian Journal of Research in Social Sciences and Humanities, 5(6), 1-10.

[9] O'Driscoll, G. P. et al. (2003). Property Rights: The Key to Economic Development. Cato Policy Analysis, (482). Washington: Cato Institute.

[10] Om Gurung. (2010). Concepts and Methods of Common Property Resource Management, Anthropology at the Central Department of Sociology/Anthropology, T. U. Kirtipur

[11] Ostrom, Elinor. (1990). Governing The Commons: The Evolution Of Institutions For Collective Action. 10.2307/3146384.

[12] Pari Baumann. (2002). Fao.org. (2018). Improving access to natural resources for the rural poor - A critical analysis of central concepts and emerging trends from a sustainable livelihoods perspective. Retrieved from http://www.fao.org/docrep/006/ad683e/ad683e01.htm\#TopOfPage [Accessed 7 Mar. 2018].

[13] RatulMahanta\& Daisy Das. (2012). Common Property Resources Degradation and Migration: A Case Study of Assam, Journal of Human Ecology, 38(3), 223-230

[14] Shiva LalBhushal. (2009). The Utilization Of Common Property Resources And Sustainable Management: A Case Study Of DobhanVdc Of Palpa,Tribhuvan University Journal, 26(1), 111. 